\title{
Pengaruh Berbagai Ketinggian Tempat terhadap Kandungan Fraksi Serat pada Rumput Lapang sebagai Pakan Hijauan
}

\author{
The Effect of Various Altitudes on Field Grass Forage Fiber Fraction Content
}

\section{N. P. Indriani, A. Rochana, H. K. Mustafa, B. Ayuningsih, I. Hernaman, D. Rahmat, T. Dhalika, K. A. Kamil dan Mansyur.}

Fakults Peternakan, Universitas Padjadjaran, Bandung, Jawa Barat, Indonesia.

Corresponding email:: popi.nyimas@gmail.com

\begin{abstract}
The field grass forage with high quality and sufficient amount was required by ruminants. fiber fraction was the component that generated energy in ruminants to improve productivity. Field grass was available enough at various altitudes (high, medium and low), particularly in rural areas in West Java. The purpose of this study was to determine the fiber fraction of the field grass in the countryside of West Java in two seasons, during dry and rain season. The study was conducted from September 2015 to July 2016. The method was a survey method, sampling was done in multistage sampling. First stage was determining areas based on the density of livestock, using purposive sampling areas of West Java. The second stage was determining the area of the selected districts and were grouped for altitude as treatments using experimental method with Completely Randomized Design. Each area had six randomized samples resulted by quadrant tool. The parameters measured in the study was the fiber fraction. The results showed that ADF and lignin in various heights are the same, while the content of NDF, Cellulose and Hemicellulose in the mediumland and lowland are the same and they are higher than in highland.
\end{abstract}

Key words: field grass, forage, altitudes, fiber fraction

\begin{abstract}
ABSTRAK
Ketersediaan rumput lapang dengan kualitas yang tinggi dan jumlah yang mencukupi sangat diperlukan ruminansia. Fraksi serat merupakan komponen sumber energi pada ruminansia untuk meningkatkan produktivitasnya. Rumput lapang cukup tersedia di berbagai ketinggian, terutama pedesaan di Jawa Barat. Tujuan dari penelitian ini adalah untuk menentukan fraksi serat dari rumput lapang di pedesaan Jawa Barat pada musim hujan dan musim kemarau. Penelitian dilakukan dari bulan September 2015 sampai Juli 2016. Metoda yang digunakan adalah metoda survei, dengan penentuan sampel secara bertahap.Tahap pertama adalah menentukan area berdasarkan jumlah ternak dengan purposive sampling untuk wilayah Jawa Barat. Tahap kedua menentukan daerah berdasarkan ketinggian tempat sebagai perlakuan menggunakan metoda eksperimental dengan Rancangan Acak Lengkap (RAL). Setiap desa mempunyai 6 cuplikan dengan cara melempar kuadran secara acak. Parameter yang diukur adalah fraksi serat. Hasil menunjukkan bahwa ADF dan Lignin sama kandungannya untuk berbagai ketinggian, sedangkan kandungan NDF, Selulosa dan hemiselulosa pada ketinggian sedang dan rendah adalah sama dan lebih tinggi dari pada di dataran tinggi.
\end{abstract}

Kata kunci : rumput lapang, hijauan, ketinggian tempat, fraksi serat

\section{PENDAHULUAN}

Keragaman jenis bahan pakan yang terdapat di Jawa Barat sangat luas sehingga daya dukungnya terhadap produksi domba sangat besar, namun potensi penyediaan bahan pakan ini masih belum dapat dimanfaatkan secara maksimal dalam penyediaan ransum karena beberapa kendala seperti jumlah biomasa yang dihasilkan dan nilai nutrisi bahan pakan belum teridentifikasi, terinventarisasi dan terukur dengan baik, sehingga potensi bahan pakan untuk mendukung produksi domba tidak dapat dipetakan sesuai kondisi wilayah yang ada, dan bahan pakan yang tersedia tidak memberikan kontribusi maksimal bagi peningkatan produksi ruminansia di Jawa Barat.

Pakan berserat yang berasal dari hijauan adalah penyusun utama ransum ternak ruminansia. Pada peternakan rakyat, terutama kelompok petani peternak yang memelihara ternak dalam kandang, hijauan yang diberikan sebagian besar berupa rumput alam yang tempat tumbuhnya bervariasi dari daerah perkebunan, kehutanan, lapangan umum, pematang sawah, 
dan di sepanjang pinggiran sungai, tanpa proses pemupukan atau perlakuan lain yang lazim dilakukan terhadap rumput budidaya (Sudirman et al., 2015). Produktivitas ruminansia sangat tergantung pada ketersediaan hijauan yang berkualitas. Ketersediaan pakan secara berkelanjutan baik kualitas maupun kuantitas, terutama disaat musim kemarau masih merupakan permasalahan utama dalam produktivitas ternak. Pemberian pakan yang efisien untuk ruminansia adalah salah satu strategi dalam memanfaatkan sumber daya lokal yang melimpah dan bernilai gizi (Indriani et al., 2019).

Neutral Detergent Fiber (NDF) tidak larut dalam detergent netral dan merupakan bagian terbesar dinding sel yang terdiri dari selulosa, hemiselulosa, lignin dan silika serta protein fibrosa. Acid Detergent Fiber (ADF) tidak larut dalam asam yang terdiri dari selulosa, , lignin dan silika. Selulosa merupakan polisakarida yang lebih tahan terhadap reaksi kimia. Hemiselulosa termasuk di dalamnya pentosa, heksosa, araban, xilan dan polinuorat yang kurang tahan terhadap pelarut kimia dan reaksi enzimatis. Lignin dan silika merupakan bagian dinding sel tanaman yang tidak dapat dicerna oleh mikroorganisme rumen. Fraksi serat sering terdapat dalam bentuk berikatan dengan lignin sehingga menjadi sulit dicerna oleh mikroba rumen (Van Soest, 1982). Selanjutnya menurut Manu (2013) bahwa kandungan kimia rumput alam ini sangat mempengaruhi kecernaan pakan, karena kecernaan berhubungan erat dengan kandungan Protein Kasar (PK) dan dinding sel (NDF). Semakin rendah PK dan semakin tinggi kandungan NDF akan semakin memperkecil kecernaan suatu bahan pakan.

Umumnya rumput lapang bisa hidup diberbagai ketinggian tempat karena sudah beradaptasi terhadap lingkungan sekitarnya dalam jangka waktu yang lama. Rumput lapang umumnya terdiri dari rumput (tanaman $\mathrm{C} 4$ ) dan legum (tanaman C3). Tanaman C4 membutuhkan sinar matahari penuh, sedangkan tanaman $\mathrm{C} 3$ merupakan tanman yang tahan naungan. Istilah tanaman C3 karena enzim Rubisco menangkap $\mathrm{CO}_{2}$ dan menggabungkannya dengan RuBP menjadi 3-fosfogliserat yang merupakan molekul berkarbon 3 (PGA), selanjutnya menuju siklus Calvin membentuk glukosa. Tanaman $\mathrm{C} 4$ karena enzim PEP karboksilase menangkap $\mathrm{CO}_{2}$ dan menggabungkannya dengan fosfoenulpiruvat menjadi Oksaloasetat (OAA) yang merupakan molekul berkarbon 4, terjadi di mesofil daun.
Selanjutnya OAA diubah menjadi malat menuju seludang pembuluh untuk melepaskan $\mathrm{CO}_{2}$, dan menjalani siklus Calvin menghasilkan karbohidrat. Menurut Widodo (2011) pada tanaman $\mathrm{C} 3$, enzim menyatukan $\mathrm{CO}_{2}$ dengan RuBP pada proses awal asimilasi dan dapat pula mengikat $\mathrm{O}_{2}$ pada saat bersamaan untuk proses fotorespirasi sedangkan pada tanaman $\mathrm{C} 4, \mathrm{CO}_{2}$ diikat oleh PEP. Enzim pengikat $\mathrm{CO}_{2}$ (PEP) tidak dapat mengikat $\mathrm{O}_{2}$ sehingga tidak terjadi persaingan antara $\mathrm{CO}_{2}$ dan $\mathrm{O}_{2}$. Konsentrasi $\mathrm{CO}_{2}$ yang tinggi pada sel-sel Bundle Sheath menyebabkan $\mathrm{O}_{2}$ tidak mendapatkan kesempatan untuk bereaksi dengan RuBP sehingga fotorespirasi sangat kecil.

Fraksi serat yang terdiri dari ADF, NDF, selulosa, hemiselulosa dan lignin, banyak terdapat pada rumput-rumputan dan kandungan seratnya lebih tinggi jika dibandingkan dengan tanaman legum (C3). Berdasarkan komposisi botanis maka diperoleh spesies rumput lapang diberbagai ketinggian tempat (rendah, sedang dan tinggi) yang terdapat pada Tabel 1 .

Menurut Susetyo (1980) produktivitas rumput lapang disamping dipengaruhi oleh ketersediaan lahan, kesuburan tanah, air,iklim, juga dipengaruhi topogafi dalam penelitian ini adalah ketinggian tempat. Penelitian fraksi serat di tiga ketinggian tempat (dataran rendah, sedang dan tinggi), adalah penting dilakukan untuk memberikan informasi dasar bagi peningkatan produktivitas ruminansia melalui revitalisasi pakan di Jawa Barat. Penelitian ini bertujuan untuk mengetahui kandungan fraksi serat rumput lapang yang berpotensi sebagai pakan ternak ruminansia pada tiga tingkat ketinggian tempat (dataran rendah, sedang dan tinggi) di wilayah Jawa Barat.

\section{MATERI DAN METODE}

Penelitian ini dilakukan pada dua musim yaitu musim kemarau dan musim hujan pada bulan September 2015 sampai bulan Juli 2016. Langkah pertama pada penelitian ini adalah melakukan inventarisasi, identifikasi, dan evaluasi kandungan zat-zat makanan dan pemetaan bahan pakan agar dapat diketahui daya dukungnya bagi peningkatan produktifitas ruminansia khususnya domba di Jawa Barat. Metode yang digunakan pada penelitian tahap pertama adalah inventarisasi berdasarkan data sekunder yang diperoleh dari BPS Jawa Barat terhadap potensi produksi hijauan (rumput, leguminosa dan gulma). 
Tabel 1. Spesies-spesies rumput lapang diberbagai ketinggian tempat (Rendah, Sedang dan Tinggi) di Jawa Barat.

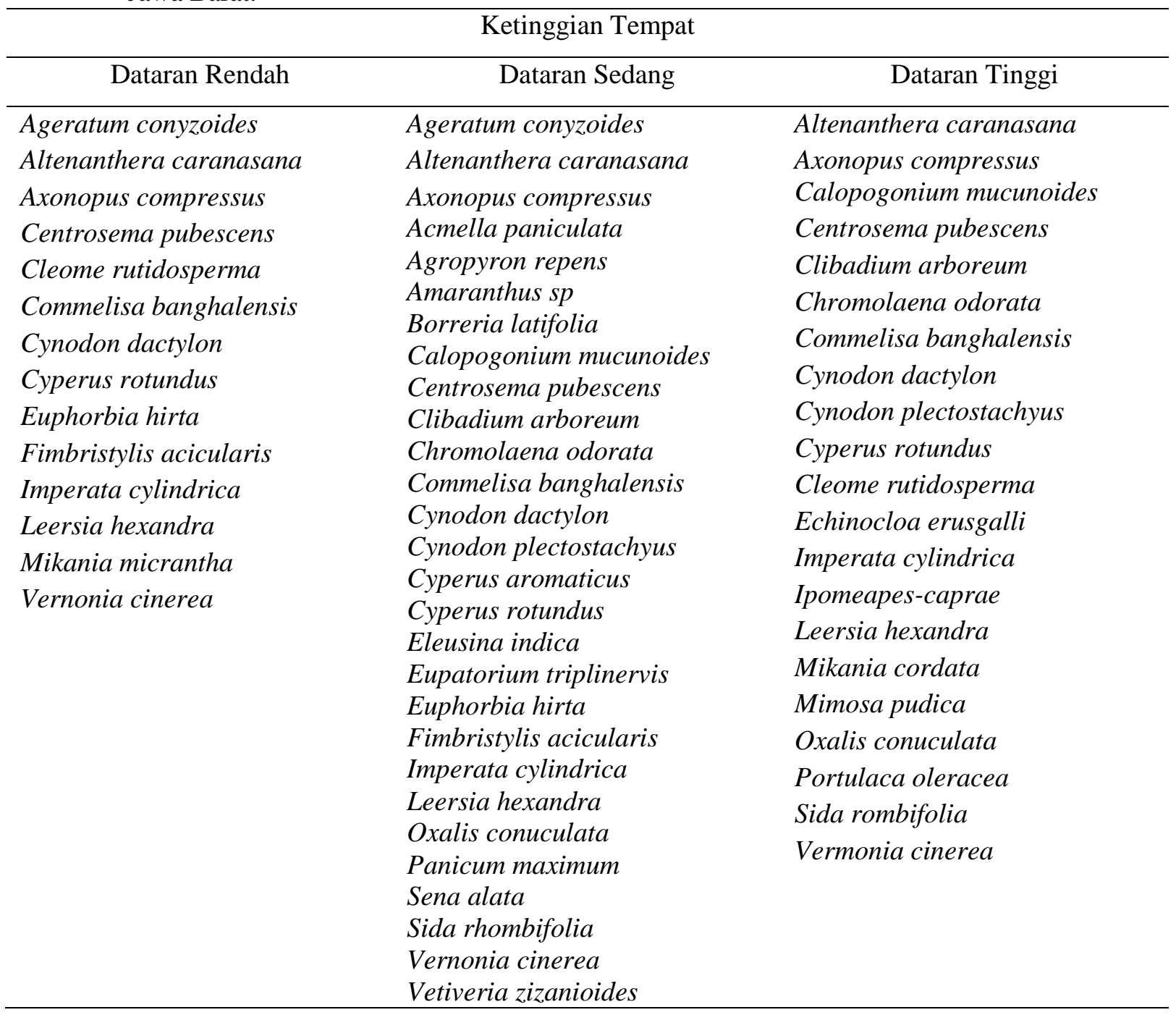

Langkah kedua penarikan sampling berdasarkan klaster. Penelitian dilakukan dengan metode survey, pengambilan sampel dilakukan secara bertahap (multistage sampling). Tahap pertama menentukan wilayah kabupaten menggunakan purposive sampling dengan pertimbangan: potensi hijauan dari rumput lapang, luas areal tanam dan kapasitas produksi, tingkat kepadatan ternak, tata guna lahan yang data dasarnya diambil dari data statistik (data sekunder) yang tersedia untuk wilayah Jawa Barat. Tahap kedua menentukan wilayah dari kabupaten terpilih berdasarkan ketinggian tempat (rendah, sedang dan tinggi) sekaligus sebagai perlakuan. Selanjutnya penentuan sampling untuk pengambilan data primer berupa produksi dan kandungan fraksi serat hijauan pakan diperoleh melalui pengambilan sampel lapangan dan analisis kimia terhadap sampel.
Tahapan pengumpulan data lapangan (data primer) dengan penaksiran komposisi botanis melalui pengukuran produksi biomassa yang terdiri dari pemotongan, penimbangan, dan pengeringan untuk bahan pakan yang termasuk klasifikasi hijauan yang diberikan segar atau pastura atau hijauan alam. Untuk mengukur produksi hijauan digunakan kuadran ukuran 0,5 x $0,5 \mathrm{~m}^{2}$. Pemotongan kelas bahan pakan ini dilakukan dengan alat pemotong antara $2,5 \mathrm{~cm}$ untuk jenis hijauan pakan ukuran kecil dan 10 $\mathrm{cm}$ dari permukaan tanah untuk hijauan pakan yang ukuran tanamannya lebih besar. Penelitian pada tahap kedua dilakukan dengan menggunakan metoda eksperimental dengan Rancangan Acak Lengkap (RAL). Setiap desa dilakukan 6 kali cuplikan dengan cara melempar kuadran secara acak. Segera setelah dipotong, bahan pakan tersebut ditimbang untuk mengukur bobot segarnya. Setelah penimbangan, sampel 
bahan pakan dimasukan ke dalam kantong kertas yang sudah diberi identitas dan telah diketahui bobotnya dan dikeringkan secara bertahap sampai bebas air, selanjutnya dilakukan analisis kimia untuk mengetahui kandungan fraksi serat.

Peubah yang diukur pada penelitian ini meliputi kandungan ADF, NDF, Cellulose, Hemicelulose dan lignin. Data yang diperoleh ditabulasikan berdasarkan ketinggian tempat (dataran rendah, sedang dan tinggi) yang telah ditetapkan, selanjutnya disajikan berdasarkan pendugaan produksi biomasa menggunakan pendugaan parameter populasi dan pembandingan potensi pakan untuk tiap ketinggian tempat menggunakan ANAVA.

\section{HASIL DAN PEMBAHASAN}

Kabupaten- kabupaten di Jawa Barat pada penelitian ini dipilih berdasarkan pertimbangan potensi biomasa rumput lapang, luas areal rumput lapang, tingkat kepadatan ternak, dan tata guna lahan yang data dasarnya diambil dari data statistik (data sekunder). Wilayah Kabupaten yang terpilih dikelompokkan berdasarkan ketinggian tempat (dataran rendah, sedang dan tinggi).

Menurut Wicaksono et al., (2015) dataran bawah atau dataran rendah adalah ketinggian tempat yang kurang dari $500 \mathrm{~m} \mathrm{dpl,}$ sedangkan dataran sedang adalah ketinggian tempat antara 500- $700 \mathrm{~m} \mathrm{dpl,} \mathrm{dan} \mathrm{untuk} \mathrm{dataran}$ atas atau tinggi adalah ketinggian tempat lebih

Table 2. Daerah terpilih sebagai sumber hijauan pakan diberbagai ketinggian di Jawa Barat.

\begin{tabular}{|c|c|c|c|}
\hline Ketinggian Tempat & Kabupaten & Kecamatan & Desa \\
\hline \multirow{10}{*}{ Dataran Rendah } & Karawang & Klari & Gintung Kerta \\
\hline & & & Klari \\
\hline & Majalengka & Jatitujuh & Pilangsari \\
\hline & & & Jatitengah \\
\hline & Garut & Pameungpeuk & Sancang \\
\hline & & & Cigodeg \\
\hline & & & Mancagahar \\
\hline & Tasikmalaya & Cipatujah & Sindangkerta \\
\hline & & & Nagrag \\
\hline & & & Cikawungading \\
\hline \multirow{12}{*}{ Dataran Sedang } & Garut & Tarogongkaler & Mekarjaya \\
\hline & & & Rancabango \\
\hline & & & Cisompet \\
\hline & & & Kertamukti \\
\hline & Majalengka & Majalengka & Babakanjawa \\
\hline & Purwakarta & Panyingkiran & Jayamukti \\
\hline & & Cempaka & Cempakasari \\
\hline & & Pasawahan & Warungkadu \\
\hline & & Purwakarta & Citalang \\
\hline & & Cipeundeuy & Nanggeleng \\
\hline & & & Bojongmekar \\
\hline & & & Cipeundeuy \\
\hline \multirow{10}{*}{ Dataran Tinggi } & Garut & Cikajang & Cikandang \\
\hline & & Ciawi & Gombong \\
\hline & Majalengka & Argapura & Sagara \\
\hline & & & Sukarati \\
\hline & Purwakarta & Wanayasa & Babakan \\
\hline & & & Semurugul \\
\hline & & & Raharja \\
\hline & Bandung Barat & Gununghalu & Celak \\
\hline & & & Saluyu \\
\hline & & & Gununghalu \\
\hline
\end{tabular}


dari $700 \mathrm{~m}$ dpl. Tanaman yang tumbuh di dataran rendah, mendapatkan intensitas cahaya matahari yang lebih banyak, sehingga sangat baik untuk rumput lapang yang sangat memerlukan sinar matahari penuh untuk kegiatan fotosintesis.

Komposisi botani rumput lapang secara umum di Wilayah Jawa Barat terdiri dari rumput, leguminosa dan gulma. Hijauan pakan yang merupakan campuran dengan tanaman leguminosa akan meningkat palatabilitas dan kecernaan ternak (Ayub et al., 2004). Hal ini sesuai dengan pendapat Rusinovci et al., (2016) bahwa hijauan didefinisikan sebagai tanaman berserat yang dipanen dan digunakan oleh ruminansia dan beberapa yang bukan ruminansia. Campuran rumput dan legum lebih disukai ruminansia dari pada hanya rumput saja dan dapat menambah total produksi untuk serat yang dominan dari rumput dan protein yang dominan dari leguminosa sehingga nutrisi menjadi seimbang.

Lokasi tumbuhnya atau persebaran jenis rumput lapang melalui komposisi botani dan ditetapkan dengan metode cuplikan menggunakan kuadran berukuran $0,25 \mathrm{~m}^{2}$. Rumput lapang merupakan asset yang sangat penting peranannya dalam menunjang pengembangan usaha ternak ruminansia terutama ternak domba. Habitat rumput lapang terdiri dari spesies rumput, legum dan gulma serta adanya tumbuhan pohon lainnya yang tumbuh secara alamiah maupun sengaja ditanam. Pengukuran produksi hijauan dilakukan dalam areal perkebunan, kehutanan, pesawahan, pinggiran jalan, penting artinya dalam menentukan peluang pengembangan ternak domba yang diusahakan petani peternak setempat.

Pada penelitian ini dilakukan di musim kemarau dan hujan yang tidak ada interaksi dan perbedaan pada kedua musim. Fraksi serat untuk NDF, Selulosa dan Hemiselulosa pada dataran tinggi berbeda nyata lebih rendah $(\mathrm{P}<0,05)$ dibandingkan pada dataran sedang dan rendah. Pada ketinggian tempat, cahaya matahari lebih rendah diterima tanaman dari pada di dataran rendah dan sedang. Rumput lapang termasuk tanaman yang membutuhkan sinar penuh untuk fotosintesis, apabila sinar matahari tidak sebanyak di dataran rendah dan sedang maka rumput lapang tinggi kadar protein dan rendah serat. Hal ini sejalan dengan pendapat Turral et al., (2011) yang mengatakan bahwa temperatur lebih tinggi yang terjadi di dataran rendah dan sedang, menghasilkan peningkatan pastura, dalam hal ini adalah NDF, selulosa dan hemiselulosa. Tanaman di dataran tinggi berkembang dengan intensitas cahaya dan suhu udara yang lebih rendah apabila dibandingkan pada dataran sedang dan rendah sehingga menghasilkan kualitas protein lebih tinggi dan berbanding terbalik untuk kandungan seratnya yang terdapat pada batang tanaman. Rochana et al. (2016) dari hasil penelitian menyatakan bahwa tanaman pakan pada dataran rendah mendapatkan radiasi matahari penuh sehingga kadar serat kasar lebih besar yang merupakan pembentuk energi bagi tanaman.

Hasil ADF dan lignin pada penelitian berbagai tingkat ketinggian tempat tidak berbeda nyata $(\mathrm{P}>0,05)$. Menurut Minson (1990) kandungan $\mathrm{ADF}$ dan lignin pada rumput-rumput tropika berturut-turut berkisar $21-55 \%$ dan 211,5\%. Pada penelitian fraksi serat di Jawa Barat kandungan ADF sesuai dengan kandungan ADF rumput-rumput tropika dan untuk kandungan lignin lebih kecil yang berkisar 0,86-1,03\%, sehingga semakin kecil kandungan lignin pada hijauan maka tingkat kecernaan pada ruminansia semakin tinggi. Rumput lapang pada penelitian ini mengandung hijauan leguminosa yang mengandung serat rendah.

Hasil penelitian tersebut sesuai dengan penelitian Tsegay et al., (2018) yang menyatakan bahwa Rumput Brachiaria cv. Eth13726 menghasilkan kandungan ADF dan lignin yang tidak berbeda diberbagai ketinggian (rendah, sedang dan tinggi).

Tabel 3. F raksi Serat pakan hijauan pada musim kemarau dan hujan di berbagai dataran di Jawa Barat

\begin{tabular}{lccccc}
\hline Tingkat & \multicolumn{5}{c}{ Fraksi Serat (\%) } \\
\cline { 2 - 6 } $\begin{array}{l}\text { Ketinggian } \\
\text { Tempat }\end{array}$ & NDF & ADF & Selulosa & Hemiselulosa & Lignin \\
\hline Dataran Rendah & $40,26 \mathrm{a}$ & $32,01 \mathrm{a}$ & $30,98 \mathrm{a}$ & $8,25 \mathrm{a}$ & $1,03 \mathrm{a}$ \\
Dataran Sedang & $41,57 \mathrm{a}$ & $32,79 \mathrm{a}$ & $32,59 \mathrm{a}$ & $8,78 \mathrm{a}$ & $1,03 \mathrm{a}$ \\
Dataran Tinggi & $37,85 \mathrm{~b}$ & $30,02 \mathrm{a}$ & $29,16 \mathrm{~b}$ & $7,83 \mathrm{~b}$ & $0,86 \mathrm{a}$ \\
\hline
\end{tabular}

Keterangan: Huruf yang berbeda pada kolom menunjukkan berbeda nyata 
Tabel 4. Fraksi Serat (NDF, ADF dan Lignin) Rumput Brachiaria Eth13726 Di Barat Laut Ethiopia

\begin{tabular}{lccc}
\hline \multirow{2}{*}{$\begin{array}{l}\text { Tingkat Ketinggian } \\
\text { Tempat }\end{array}$} & \multicolumn{3}{c}{ Fraksi Serat (\%) } \\
\cline { 2 - 4 } & NDF & ADF & Lignin (ADL) \\
\hline Dataran Rendah & $71,70 \mathrm{a}$ & $50,99 \mathrm{a}$ & $30,98 \mathrm{a}$ \\
Dataran Sedang & $67,57 \mathrm{a}$ & $51,02 \mathrm{a}$ & $32,59 \mathrm{a}$ \\
Dataran Tinggi & $69,42 \mathrm{a}$ & $50,29 \mathrm{a}$ & $29,16 \mathrm{a}$ \\
\hline Keterangan: Huruf yang berbeda pada kolom menunjukkan berbeda nyata
\end{tabular}

Keterangan: Huruf yang berbeda pada kolom menunjukkan berbeda nyata

Hal tersebut secara terperinci dapat dilihat pada Tabel 3. Rumput Brachiaria cv.Eth13726 menghasilkan produksi yang lebih tinggi dan kandungan zat-zat makanan (komposisi kimia) yang lebih baik dari pada rumput lapang atau rumput alami.

\section{KESIMPULAN}

Hasil hijauan dari rumput lapang yang terdiri dari rumput, legum dan gulma menunjukkan bahwa kandungan ADF dan Lignin adalah sama untuk berbagai ketinggian, sedangkan kandungan NDF, Selulosa dan hemiselulosa pada ketinggian sedang dan rendah adalah sama dan lebih tinggi dari pada di dataran tinggi

\section{SARAN}

Penelitian selanjutnya direkomendasikan untuk kecernaan hijauan dari Rumput Lapang yang terdiri dari rumput, legum dan gulma secara in vitro dan in vivo pada ruminansia

\section{DAFTAR PUSTAKA}

Ayub, M., A. Tanveer, M.A. Nadeem and S. M. A. Shah. 2004. Studies on the fodder yield and quality of sorghum grown alone and in mixture with rice bean. Pakistan Journal of Life and Social Sciences. 2 (1): 46-46.

Indriani, N.P., H.K. Mustafa, B. Ayuningsih Mansyur and A. Rochana. 2019. Production and nitrogen, phosphorus and calcium absorption of sword bean leaf (Canavalia gladiata) in application of rock phosphate and VAM inoculation. Legume Research. 42(2):238-242. DOI: 10.18805/LR-422.
Manu, A.E. 2013. Produktivitas Padang Penggembalaan Sabana Timor Barat. Jurnal Pastura 3(1): 25-29.

Minson, D.J. 1990. The Chemical Composition and Nutritive Value of Tropical Grasses. In: (Skerman, P.J. Cameroon, D.G, and F. Riveros) Tropical grasses. pp. 172 180. Food and Agriculture Organizationof the United Nations, Rome.

Rochana, A., N. P. Indriani, B. Ayuningsih, I. Hernaman, T. Dhalika, D. Rahmat and S. Suryanah. 2016. Feed forage and nutrition value at altitudes during the dry season in West Java. Animal Production 18(2):85-93

Rusinovci, I., S. Aliu, S. Fetahu and D.Zeka. 2016. The agronomic performance of some grass mixtures in the prishtina locality. Journal of Food, Agricultures Environment 14(2): 117-120

Sudirman, Suhubdy, S.D.Hasan, S.H.Dilaga, I.W.Karda.2015. Kandungan Neutral Detergent Fibre (NDF) dan Acid Detergent Fibre (ADF) bahan pakan lokal ternak sapi yang dipelihara pada kandang kelompok. Jurnal Ilmu dan Teknologi Peternakan Indonesia. 1(1):6670.

Susetyo, S. 1980. Padang Penggembalaan. Direktorat Bina Sarana Usaha Peternakan. Direktorat Jendral Peternakan. Departemen Pertanian. Indonesia.

Tsgay, B.A., A.T.Wolde, and B.A.Limeneh.2018. Evaluation of morphological characteristics, yield and nutritive value of Brachiaria grass ecotypes in Nort 
Western Ethiopia. Agriculture \& Food Security 7(89):1-10.

Turral, H., J.Burke and J.M.Faures. 2011. Climate change, water and food security.FAO.Water Respons. Rome. 27

Van Soest, P.J. 1982. Nutritional Ecology of The Ruminant. Commstock Publishing Associates. A devision of Cornell University Press. Ithaca and London.
Wicaksono, H., E.T.S. Putra dan S. Muhartini. 2015. Kesesuaian tanaman ganyong (Canna indica L) Suweg (Amorphophallus paeoniifolius (Dennst) Nilcolson), dan Ubi Kayu (Manihot esculenta Crantz) pada Agriforestri Perbukitan Menoreh. Vegetalika. 4(1):87-101.

Widodo, Y. 2011. Strategi sinergistik peningkatan produksi pangan dalam hutan lestari melalui wanatani. Pangan, 20 (3):251-270. 